\title{
Effect of potash and sulphur on yield and quality parameters under different planting methods in onion
}

\author{
Balvir Kaur, Paramjit Kaur Sraw*, Amanpreet Kaur and Kuldeep Singh \\ Krishi Vigyan Kendra, Jalandhar, Punjab Agricultural University, Ludhiana (Punjab), INDIA \\ *Corresponding author. E-mail: parampahul78@pau.edu
}

Received: April 5, 2017; Revised received: June 27, 2017; Accepted: November 5, 2017

Abstract: A field experiment was carried out to examine the effect of potash and sulphur on yield and quality parameters under different planting methods in onion (Allium cepa L.) during Rabi 2014 and 2015. The experiment consists of 8 treatment combinations viz. 2 planting methods (bed and flat), 4 treatments of fertilizer viz. $S_{1}-N_{100} P_{50} K_{0}$ $S_{0}$ (control), $S_{2}-N_{100} P_{50} K_{50} S_{0}, S_{3}-N_{100} P_{50} K_{0} S_{40}, S_{4}-N_{100} P_{50} K_{50} S_{40}$. The experiment was laid in factorial randomized block design and replicated thrice. Uniform dose of farm Yard manure $\left(50 \mathrm{t} \mathrm{ha}^{-1}\right)$ was applied to all the treatments. Data on plant height $(\mathrm{cm})$, leaves /plant (No.), neck thickness $(\mathrm{mm})$, fresh bulb weight $(\mathrm{g})$, fresh bulb yield (q ha ${ }^{-1}$ ), total soluble solids (T.S.S), sprouting (\%),rotting (\%) and physiological weight loss (\%) at 30 and 90 days after of harvest were recorded. It has been observed that planting methods and fertilizer treatments showed significant difference at $5 \%$ level of significance for plant height $(\mathrm{cm})$, neck thickness $(\mathrm{mm})$, fresh bulb weight $(\mathrm{g})$, fresh bulb yield $\left(\mathrm{q} \mathrm{ha} \mathrm{h}^{-1}\right)$, total soluble solids (T.S.S), sprouting(\%), rotting(\%) and physiological weight loss $(\%)$ at 30 days after harvest. However their interaction was significant for Neck thickness $(\mathrm{mm})$, fresh bulb yield $\left(\mathrm{q} \mathrm{ha}^{-1}\right)$ and rotting (\%).It was found that application of potash and sulphur with recommended dose of Nitrogen and phosphorus gave better results in relation to yield as well as quality characters. The results revealed that application of potash and sulphur with recommended dose of nitrogen and phosphorus $\left(S_{4}-N_{100} P_{50} K_{50} S_{40}\right)$ gave better results in relation to yield (339.6 q ha- ${ }^{1}$ ) as well as quality characters like sprouting $(2.38 \%)$ and rooting $(12.18 \%)$ and physiological weight loss at 30 and 90 days of harvest(10.22 and $20.50 \%$ respectively).

Keywords: Onion, Potash, Sulphur, Yield and quality parameters

\section{INTRODUCTION}

Onion (Allium cepa L.) "Queen of the Kitchen" belongs to family Alliaceas, one of the most commercially valuable vegetables grown in India. It considered as a rich source of carbohydrates, proteins, vitamin $\mathrm{C}$ besides minerals like phosphorus and calcium. Onions contain quercetin, a flavonoid which helps to eliminate free radicals in the human body, to inhibit low density lipoprotein oxidation to protect and regenerate vitamin $\mathrm{E}$ and inactivate the harmful effects of chelate metal ions (Scott, 2007) . India is the second largest producer of onion in the world, next to China with an area of 1.05 million hectares with production of 16.81 million tonnes (Anonymous, 2014) but the productivity is low $14.85 \mathrm{t} \mathrm{ha}^{-1}$ as compared to other countries. Intensive cropping, imbalanced fertilization, minimal usage of micro nutrients and limited application of organic manures have resulted in the depletion of soil fertility could have resulted in low productivity and quality of the crop which may be enhanced by proper planting method as well as nutrient management practices .Among the methods of planting, flat planting is recommended method of planting by Punjab Agricultural University Ludhiana but farmers of district Jalandhar mostly practiced the bed planting as sole crop or ISSN : 0974-9411 (Print), 2231-5209 (Online) All Rights Reserved $\odot$ Applied and Natural Science Foundation www.jans.ansfoundation.org intercrop with other vegetable crops. They claimed that comparatively larger size bulbs are obtained with bed planting which fetch better profit in market. Fertilizer management is one of the important management factors that may contribute much to the onion yield. Nitrogen, potassium and sulphur are important nutrient element that play important role on bulb formation, elongation, skin color development and pungency of onion (Vachhani and Patel. 1993).Similarly, storage life of onion is also important factor to sell the onion in off season for better profit market. Potash and sulphur play important role to decrease the post harvest losses in onion which ranged from $25-60 \%$ in onion. Potassium plays a vital role in plant metabolism such as photosynthesis, translocation of photosynthates, regulation of plant pores, activation of plant catalysts and resistance against pests and diseases. It also improves quality parameters of many crops including onion like colour, glossiness and dry matter accumulation besides improving keeping quality of the onion (Subhani et al., 1990).Sulphur is also known to improve the yield and quality parameters of important vegetable crops. Sulphur requirement of vegetable crops is almost similar to that of phosphorus. Sulphur is aconstituent of secondary compounds viz., allin, cycloallin and thiopropa- 
nol which not only influence the taste, pungency, medicinal properties of onion and garlic besides inducing resistance against pests and diseases. Sulphur is also required for the synthesis of three important essential amino acids such as cystine $(27 \% \mathrm{~S})$, cysteine $(26 \% \mathrm{~S})$ and methionine $(21 \% \mathrm{~S})$ besides increasing allyl propyl disulphide alkaloid $(43 \% \mathrm{~S})$ and the capsaicin, the principle alkaloids responsible for pungency in onion and chilli, respectively (Randle and Bussard, 1993).Generally, Punjab soils are rich in potassium and its application is recommended only on soil test basis in most of field crops. Similarly, deficiency of sulphur is observed in light texture soils. But it has been observed that majority of farmers are not aware about balance use of potassium and sulphur along with nitrogen and phosphorus in onion. The present experiment was therefore, designed with an emphasis on application of different combination of ferlizers since vegetative growth, bulb production and storability is important for economic valve of this crop. However, this study was undertaken to find out the effect of potash and sulfur application along with recommended doses of nitrogen and phosphorus for higher yield and storability of onion under different planting methods in onion.

\section{MATERIALS AND METHODS}

The field experiment was conducted at Krishi Vigyan Kendra, Jalandhar, Punjab to study the effect of potash and sulphur on yield and quality parameters of onion under different planting methods during 2014 and 2015 in Rabi season. Krishi Vigyan Kendra, Jalandhar is geographically situated at $31^{\circ} 09^{\prime} \mathrm{N}$ latitude, $75^{\circ} 59^{\prime} \mathrm{E}$ longitude and atan altitude of about $237 \mathrm{~m}$ above mean sea level. The experiment was laid out in factorial randomized complete block design and replicated thrice. The experiment consists of 8 treatment combinations viz. 2 planting methods (bed and flat), 4 treatments of fertilizer viz. $\mathrm{S}_{1}-\mathrm{N}_{100} \mathrm{P}_{50} \mathrm{~K}_{0} \mathrm{~S}_{0}$ (control), $\mathrm{S}_{2}$ -

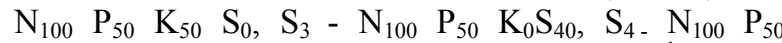
$\mathrm{K}_{50}$.Well rotten farm Yard manure @ $50 \mathrm{t} \mathrm{ha}^{-1}$ recommended by Punjab Agricultural University Ludhiana was applied uniformly in the experimental field before preparatory tillage. The experimental site was sandy loam in texture, low in organic carbon (0.31) with available nitrogen (192 $\left.\mathrm{kg} \mathrm{ha}^{-1}\right)$, high in available phosphorus $\left(29.7 \mathrm{~kg} \mathrm{ha}^{-1}\right)$ and medium in available potassium $\left(149 \mathrm{~kg} \mathrm{ha}^{-1}\right)$ in $0-15 \mathrm{~cm}$ soil depth. The nursery of onion (cv. Punjab Naroya) was sown on raised beds using seed rate $10 \mathrm{~kg} \mathrm{ha}^{-1}$ in last week of October. The transplanting of the onion seedlings in the field was done in first fortnight of January in both the years following $15 \times 7.5 \mathrm{~cm}$ row to row and plant to plant spacing under flat planting and $12 \times 7.5 \mathrm{~cm}$ on beds with 4 rows on each bed $(67.5 \mathrm{~cm}$ bed size $)$. The fertilizer sources used were urea for $\mathrm{N}(46 \% \mathrm{~N})$, diammonium phosphate for $\mathrm{P}\left(18 \% \mathrm{~N}\right.$ and $\left.46 \% \mathrm{P}_{2} \mathrm{O}_{5}\right)$, muriate of potash for $\mathrm{K}\left(60 \% \mathrm{~K}_{2} \mathrm{O}\right)$ and gypsum for $\mathrm{S}$. Full dose of phosphorus, potash, sulphur and half nitrogen was applied before transplanting. The remaining dose of nitrogen was top dressed after one month of transplanting. The uprooting of the bulbs was done manually in the first week of May during Rabi 2014 and last week April during Rabi 2015. After harvesting, the bulbs were cured and then leaves were cut 1-2 $\mathrm{cm}$ above the neck and bulb yield was recorded. Data on plant height $(\mathrm{cm})$, leaves /plant (No.), neck thickness $(\mathrm{mm})$, fresh bulb weight $(\mathrm{g})$, fresh bulb yield (qha ${ }^{1}$ ), total soluble solids (T.S.S), sprouting (\%),rotting (\%) and physiological weight loss (\%) at 30 and 90 days after harvest were recorded. Data on growth and yield parameters were recorded from ten randomly selected plants from each plot. TSS was taken by using the Refractometer and data on neck thickness was taken by using Vernier caliber. The data collected on various parameters under study were statistically analyzed with CPCS1 software and comparisons were made at 5 per cent level of significance.

\section{RESULTS AND DISCUSSION}

Effect on yield and yield attributes: The yield and yield attributes showed a significant variation among all the treatments (Table 1).It was found that plant height differ significantly in both the plant methods. It was found higher $(65.3 \mathrm{~cm})$ in flat planting treatments than Bed planting(58.5) but the interaction between planting method and plant height was found non significant. It was also reported that plant height $(\mathrm{cm})$ was found highest in $\mathrm{S}_{4}-\mathrm{N}_{100} \mathrm{P}_{50} \mathrm{~K}_{50} \mathrm{~S}_{40}$ (67.6) followed by $\mathrm{S}_{3}-\mathrm{N}_{100} \mathrm{P}_{50} \quad \mathrm{~K}_{0} \mathrm{~S}_{40}$ (62.5) and $\mathrm{S}_{2}$ (61.4) which were statically at par with each other while minimum plant height was recorded in $\mathrm{S}_{1}-\mathrm{N}_{100} \mathrm{P}_{50} \mathrm{~K}_{0} \mathrm{~S}_{0}$ (56.2). Number of leaves per plant did not differ significantly in main (planting methods) as well as in interaction. But within fertilizer levels there was found significant difference which indicated that number of leaves per plant was found highest in $\mathrm{S}_{4}-\mathrm{N}_{100} \mathrm{P}_{50} \mathrm{~K}_{50} \mathrm{~S}_{40}$ (8.65) which was stastically at par with $\mathrm{S}_{3}-\mathrm{N}_{100} \mathrm{P}_{50} \mathrm{~K}_{0} \mathrm{~S}_{40}$ (8.00). Minimum numbers of leaves per plants were recorded in $\mathrm{S}_{1} \mathrm{~N}_{100} \mathrm{P}_{50} \mathrm{~K}_{0} \mathrm{~S}_{0}$ (6.19). There was significant difference in regards to neck thickness $(\mathrm{mm})$ in flat (8.26) and bed planting (6.80).It was further reported that significant interaction were found between planting methods and fertilizer levels for neck thickness. Within the fertilizers treatments, neck thickness did not differ significantly in all the fertilizer treatments. Bulb weight (g) differs significantly with regard to different planting methods. It was found higher in Bed planting (66.0) than Flat planting method (58.0).Highest bulb weight was recorded in $\mathrm{S}_{4}-\mathrm{N}_{100}$ $\mathrm{P}_{50} \mathrm{~K}_{50} \mathrm{~S}_{40}$ (75.0) followed by $\mathrm{S}_{3}-\mathrm{N}_{100} \mathrm{P}_{50} \mathrm{~K}_{0} \mathrm{~S}_{40}(64.0)$ where as lowest bulb weight was recorded in $\mathrm{S}_{1}-\mathrm{N}_{100}$

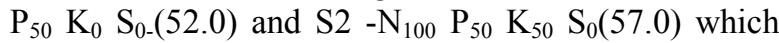
were stastically at par with each other. Ghaffoor et al. 
Balvir Kaur et al. / J. Appl. \& Nat. Sci. 9 (4): 2434 - 2437 (2017)

Table 1. Effect of planting methods and fertilizer treatments on yield and yield attributes in onion.

\begin{tabular}{|c|c|c|c|c|c|}
\hline Treatment & $\begin{array}{l}\begin{array}{l}\text { Plant height } \\
\text { (cm) }\end{array} \\
\end{array}$ & $\begin{array}{l}\text { Leaves/ } \\
\text { plant (No.) }\end{array}$ & $\begin{array}{ll}\begin{array}{l}\text { Neck } \\
(\mathrm{mm})\end{array} & \text { thickness } \\
\end{array}$ & $\begin{array}{l}\begin{array}{l}\text { Bulb weight } \\
\text { (g) }\end{array} \\
\end{array}$ & $\begin{array}{l}\text { Fresh bulb yield (q } \\
\text { ha }^{-1} \text { ) }\end{array}$ \\
\hline \multicolumn{6}{|l|}{ Planting methods } \\
\hline $\mathrm{T}_{1}$-Bed & 58.5 & 7.45 & 6.80 & 66.0 & 288.8 \\
\hline $\mathrm{T}_{2}$-Flat & 65.3 & 7.80 & 8.26 & 58.0 & 304.3 \\
\hline $\mathrm{CD}(\mathrm{P}=\mathbf{0 . 0 5})$ & 2.6 & NS & 0.40 & 3.5 & 6.30 \\
\hline \multicolumn{6}{|c|}{ Fertilizer Treatments } \\
\hline $\mathrm{S}_{1}-\mathrm{N}_{100} \mathrm{P}_{50} \mathrm{~K}_{0} \mathrm{~S}_{0}$ & 56.2 & 6.19 & 7.13 & 52.0 & 247.8 \\
\hline $\mathrm{S}_{2}-\mathrm{N}_{100} \mathrm{P}_{50} \mathrm{~K}_{50} \mathrm{~S}_{0}$ & 61.4 & 7.66 & 7.36 & 57.0 & 282.4 \\
\hline $\mathrm{S}_{3}-\mathrm{N}_{100} \mathrm{P}_{50} \mathrm{~K}_{0} \mathrm{~S}_{40}$ & 62.5 & 8.00 & 7.70 & 64.0 & 316.4 \\
\hline $\mathrm{S}_{4}-\mathrm{N}_{100} \mathrm{P}_{50} \mathrm{~K}_{50} \mathrm{~S}_{40}$ & 67.6 & 8.65 & 7.94 & 75.0 & 339.6 \\
\hline $\mathrm{CD}(\mathrm{P}=0.05)$ & 3.7 & 0.79 & 0.57 & 4.9 & 8.9 \\
\hline $\mathbf{A x B}$ & NS & NS & 0.81 & NS & 12.5 \\
\hline
\end{tabular}

Table 2. Effect of planting methods and fertilizer treatments on quality attributes in onion.

\begin{tabular}{llllll}
\hline Treatment & T.S.S (\%) & Sprouting (\%) & \multicolumn{2}{c}{ Rotting (\%) } & \multicolumn{2}{l}{ Physiological weight loss (\%) } \\
\hline Planting methods & & & & 30 DAH & 90 DAH \\
\hline $\mathrm{T}_{1}-\mathrm{Bed}$ & 10.90 & 3.59 & 24.21 & 14.39 & 25.53 \\
$\mathrm{~T}$ & 10.97 & 4.28 & 21.38 & 12.58 & 25.55 \\
CD(Plat & $\mathrm{NS}$ & 0.64 & 1.57 & 1.22 & $\mathrm{NS}$ \\
\hline Fertilizer Treatments & & & & & \\
\hline $\mathrm{S}_{1}-\mathrm{N}_{100} \mathrm{P}_{50} \mathrm{~K}_{0} \mathrm{~S}_{0}$ & 9.28 & 5.91 & 30.63 & 17.11 & 29.90 \\
$\mathrm{~S}_{2}-\mathrm{N}_{100} \mathrm{P}_{50} \mathrm{~K}_{50} \mathrm{~S}_{0}$ & 10.63 & 4.81 & 25.33 & 13.74 & 27.10 \\
$\mathrm{~S}_{3}-\mathrm{N}_{100} \mathrm{P}_{50} \mathrm{~K}_{0} \mathrm{~S}_{40}$ & 11.78 & 2.63 & 23.05 & 12.86 & 24.66 \\
$\mathrm{~S}_{4}-\mathrm{N}_{100} \mathrm{P}_{50} \mathrm{~K}_{50} \mathrm{~S}_{40}$ & 12.06 & 2.38 & 12.18 & 10.22 & 20.50 \\
$\mathbf{C D}(\mathbf{P}=\mathbf{0 . 0 5})$ & 0.58 & 0.91 & 2.22 & 1.73 & 3.28 \\
AxB & $\mathrm{NS}$ & $\mathrm{NS}$ & 3.14 & $\mathrm{NS}$ & $\mathrm{NS}$ \\
\hline
\end{tabular}

(2003) also reported that as average bulb weight increases with increases in potash level in onion. Interaction between planting method and bulb weight was found to be non significant. Data further concluded that Fresh bulb yield ( $\left.\mathrm{q} \mathrm{ha}^{-1}\right)$ differ significantly in both planting methods. Fresh bulb yield $\left(\mathrm{q} \mathrm{ha}^{-1}\right)$ was recorded higher in Flat planting (304.3) than Bed Planting (288.8) due to more number of plants per $\mathrm{m}^{2}$ area. Similarly their interaction was found to be significant in relation to fertilizer levels. Fresh bulb yield (q ha $^{-1}$ ) was found highest in $\mathrm{S}_{4}-\mathrm{N}_{100} \mathrm{P}_{50} \mathrm{~K}_{50} \mathrm{~S}_{40}$ (339.6) followed by $\mathrm{S}_{3}-\mathrm{N}_{100} \mathrm{P}_{50} \mathrm{~K}_{0} \mathrm{~S}_{40}$ (316.4) and $\mathrm{S}_{2}-\mathrm{N}_{100} \mathrm{P}_{50}$ $\mathrm{K}_{50} \mathrm{~S}_{0}(282.4)$ and minimum Fresh bulb yield ( $\left.\mathrm{q} \mathrm{ha}^{-1}\right)$ was recorded in $\mathrm{S}_{1}-\mathrm{N}_{100} \mathrm{P}_{50} \mathrm{~K}_{0} \mathrm{~S}_{0}$ (247.8). Jaggi (2005) and Mishu et al (2013) concluded that application of $40 \mathrm{~kg} \mathrm{~S}^{-1}$ resulted in the highest yield (10.6 t $\mathrm{ha}^{-1}$ ) among the different doses of sulphur in onion where as results were also supported by Dabhi et al (2004) who concluded that application of $30 \mathrm{~kg} \mathrm{ha}^{-1}$ of sulphur in form of gypsum recorded the higher values of yield parameters (plant height, number of leaves plant-1, bulb diameter and bulb weight) and highest bulb yield (246.50 q ha $\mathrm{q}^{-1}$ ) in onion. The application of 100\% recommended dose of fertilizer (100:50:50 $\mathrm{N}: \mathrm{P}_{2} \mathrm{O}_{5}: \mathrm{K}_{2} 0 \mathrm{~kg} \mathrm{ha}^{-1}$ ) either two or three splits through $\mathrm{CF}$ to onion appears to be improving soil fertility, yield $\left(22.34 \mathrm{t} \mathrm{ha}^{-1}\right)$,yield contributing character of onion and getting higher net monetary returns (Kamble and Kathmale 2015). Nasreen et al., (2007) also reported that the addition of nitrogen and sulphur fertilizers exerted significant influence on the number of leaves/plant, plant height, diameter of bulb, single bulb weight and yield of onion. The results were also supported by Mozumber et al. (2007) where maximum plant height $(41.8 \mathrm{~cm})$, length of bulb $(4.49 \mathrm{~cm})$ and diameter of bulb $(3.85 \mathrm{~cm})$, single bulb weight $(41.4 \mathrm{~g})$, fresh yield $\left(10.33 \mathrm{t} \mathrm{ha}^{-1}\right)$ were obtained with the treatment of application of $125 \mathrm{~kg} \mathrm{~N} \mathrm{ha}^{-1}, 175 \mathrm{~kg} \mathrm{~K} \mathrm{ha}^{-1}$ and 24 $\mathrm{Kg} \mathrm{ha}^{-1}$. The maximum bulb dry matter $(9.23 \%)$ content and bulb yield $\left(9.33 \mathrm{t} \mathrm{ha}^{-1}\right)$ were produced from the application of sulphur@30 kg/ha was recorded by Rashid (2010).

Effect on quality characters: Quality characters viz. total soluble solids (T.S.S), sprouting (\%), rotting (\%), physiological weight loss (30 DAH) were significantly differ with regards to different treatment on bed and flat planting (Table 2) where as there was no significant difference in charters like T.S.S and physiological weight loss (\%) in 90 Days after harvest. T.S.S did not differ significantly in relation to planting methods and interaction with the fertilizer levels. But with fertilizer levels T.S.S was recorded higher in $\mathrm{S}_{4}-\mathrm{N}_{100} \mathrm{P}_{50} \mathrm{~K}_{50} \mathrm{~S}_{40}$ (12.06) which was stastically at par with $\mathrm{S}_{3}-\mathrm{N}_{100} \mathrm{P}_{50}$ $\mathrm{K}_{0} \mathrm{~S}_{40}$ (11.78). Sprouting (\%) did not differ significantly in both the planting methods as well as their interaction with the fertilizer levels. In case of sprouting (\%), It was found higher in $\mathrm{S}_{1}-\mathrm{N}_{100} \mathrm{P}_{50} \mathrm{~K}_{0} \mathrm{~S}_{0}(5.91)$ followed by $\mathrm{S}_{2}-\mathrm{N}_{100} \mathrm{P}_{50} \mathrm{~K}_{50} \mathrm{~S}_{0}(4.81)$ and minimum in $\mathrm{S}_{4}$ $\mathrm{N}_{100} \mathrm{P}_{50} \mathrm{~K}_{50} \mathrm{~S}_{40}$ (2.38) followed by $\mathrm{S}_{3}-\mathrm{N}_{100} \mathrm{P}_{50} \mathrm{~K}_{0} \mathrm{~S}_{40}$ (2.63). This was concluded that application of potash and sulphur fertilizers decreased sprouting (\%). Rotting $(\%)$ also differ significantly in both the planting 
methods and found higher in bed planting (24.21) than flat planting (21.38). It might be due to more bulb weight in bulb weight in bed planting. Interaction between planting methods and fertilizer for rotting (\%) was found significant. Rotting (\%) was found minimum in $\mathrm{S}_{4}-\mathrm{N}_{100} \mathrm{P}_{50} \mathrm{~K}_{50} \mathrm{~S}_{40}$ (12.18) followed by $\mathrm{S}_{3}$ $\mathrm{N}_{100} \mathrm{P}_{50} \mathrm{~K}_{0} \mathrm{~S}_{40}$ (23.05) and $\mathrm{S}_{2}-\mathrm{N}_{100} \mathrm{P}_{50} \mathrm{~K}_{50} \mathrm{~S}_{0}$ (25.33) which were statistically at par with each other. Physiological weight loss (\%) after $30 \mathrm{DAH}$ was differ significantly in bed and flat planting where it found higher in bed Planting (14.39) than Flat planting(12.58), but in regards to interaction of planting methods and fertilizer for Physiological weight loss (\%) at 30 Days of harvest and physiological weight loss (\%) at 90 Days of harvest, there was no significant different. Within the fertilizer treatment physiological weight loss (\%) at 30 Days of harvest was found maximum in $\mathrm{S}_{1}-\mathrm{N}_{100} \mathrm{P}_{50} \mathrm{~K}_{0} \mathrm{~S}_{0}$ (17.11) while minimum physiological weight loss (\%) at 30 Days was recorded in $\mathrm{S}_{4}-\mathrm{N}_{100}$ $\begin{array}{llllll}\mathrm{P}_{50} & \mathrm{~K}_{50} & \mathrm{~S}_{40} & (10.22) \text {,followed by } \mathrm{S}_{3}-\mathrm{N}_{100} & \mathrm{P}_{50} & \mathrm{~K}_{0} \mathrm{~S}_{40^{-}}\end{array}$ (12.86) and $\mathrm{S}_{2}-\mathrm{N}_{100} \quad \mathrm{P}_{50} \quad \mathrm{~K}_{50} \mathrm{~S}_{0}(13.74)$ which were statiscally at par with each other. There was significant difference in physiological weight loss (\%) at 90 Days of harvest within the fertilizer treatments. Minimum physiological weight loss (\%) at 90 Days of harvest was observed in $\mathrm{S}_{4}-\mathrm{N}_{100} \mathrm{P}_{50} \mathrm{~K}_{50} \mathrm{~S}_{40}$ (20.50) followed by $\mathrm{S}_{3}-\mathrm{N}_{100} \mathrm{P}_{50} \mathrm{~K}_{0} \mathrm{~S}_{40}-(24.66)$ which was stastically at par with $\mathrm{S}_{2}-\mathrm{N}_{100} \mathrm{P}_{50} \mathrm{~K}_{50} \mathrm{~S}_{0}$ (13.74). Similar types of results were recorded by Tripathy et al. (2013) where application of sulphur in form of gypsum resulted in significantly highest plant height $(54.51 \mathrm{~cm})$ and more number of leaves per plant (14.80), heaviest bulb weight $(60.83 \mathrm{~g})$, total bulb yield $(211.23 \mathrm{q} \mathrm{ha}-1)$, higher bulb TSS $(8.48 \%)$ and better keeping quality parameters such as physiological losses of weight (18.25\%), rotting $(10.09 \%)$ and sprouting (17.35\%). Poornima et al (2015) reported that quality parameters of both onion and chilli increased with the individual application of $100 \mathrm{~kg} \mathrm{~K}_{2} \mathrm{O} \mathrm{ha}^{-1}$ and $30 \mathrm{~kg} \mathrm{~S} \mathrm{ha}^{-1}$

\section{Conclusion}

The study revealed that planting methods and fertilizer treatments showed statistically significant difference for plant height $(\mathrm{cm})$, neck thickness $(\mathrm{mm})$, fresh bulb weight $(\mathrm{g})$, fresh bulb yield $\left(\mathrm{q} \mathrm{ha}^{-1}\right)$, T.S.S (\%), sprouting (\%), rotting (\%) and physiological weight loss $(\%)$ at $30 \mathrm{DAH}$. However the interaction between fertilizer and planting methods was found significant for neck thickness $(\mathrm{mm})$, fresh bulb yield $\left(\mathrm{q} \mathrm{ha}^{-1}\right)$ and rotting (\%). It was found that application of $50 \mathrm{~kg}$ potash $\mathrm{ha}^{-1}$ and $40 \mathrm{~kg}$ sulphur ha ${ }^{-1}$ with recommended dose of Nitrogen (100 Kg ha ${ }^{-1}$ ) and phosphorus (50 kg ha $\left.{ }^{-1}\right)$ gave better results in relation to yield $\left(339.6 \mathrm{q} \mathrm{ha}^{-1}\right)$ as well as quality characters like sprouting $(2.38 \%)$ and rooting $(12.18 \%)$ and physiological weight loss at 30 and 90 days of harvest (10.22 and $20.50 \%$ respectively) in bed and flat planting.

\section{REFERENCES}

Anonymous (2014). National Horticultural Board, (http:// nhb.gov.in / area\% production, html).

Dabhi, N. M., Patel, M. V. and Patel, V. R. (2004) Effect of sources and levels of sulphur on yield and chemical composition of onion in loamy sand. National Seminar on Development in Soil Science: 69th Annual Convention, Hyderabad, October 27-30, p. 124.

Ghaffoor, A. M; Jilani, S., Khaliq, G. and Waseem, K. (2003). Effect of different NPK levels on the growth and yield of three onion (Allium cepa L.) varieties. Asian Journal of Plant Science, 2(3):342- 346

Jaggi, R. C. (2005) Sulphur as production and protection agent in onion (Allium cepa).Indian Journal Agricultural Science, 75(12): $805-808$.

Kamble, B.M. and Kathmale, D. K. (2015). Effect of different levels of customized fertilizer on soil nutrient availability, yield and economics of onion. Journal of Applied and Natural Science, 7 (2): 817 - 821.

Mishu, H. M; Ahmed, F ; Rafii, M. Y., Faruq, G. and Latif, M. A. (2013). Effect of sulphur on growth, yield and yield attributes in onion (Allium cepa L.) Australian Journal of Crop Science, 7(9): 1416-1422.

Mozumber, S. N; Moniruzzaman, M. and Halim G. M. A (2007). Effect of N, K and S on the yield and storability of transplanted onion (Allium cepa L.) in the Hilly Region. Journal of Agriculture Rural Development, 5 (1\&2): 58-63.

Nasreen,S., Haque, M. M., Hossain, M. A. and Farid , A. T. M. (2007). Nutrient uptake and yield of onion as influenced by nitrogen and sulphur fertilization. Bangladesh Journal of Agricultural Research, 32 (3): 413-420.

Poornima, K. S; Mamatha, N. and Ramesh, H. S. (2015). Effect of potassium and sulphur on quality parameters of onion and chilli intercrops in a vertisol. Advance Research Journal of Crop Improvement, 6 (2): 166-169.

Randle, W. M. and Bussard, M. L. (1993). Pungency and sugars of short day onion as affectedby sulphur nutrition. Journal of American Society of Horticulture Science, 118(6): 766-770.

Rashid, M. H. A. (2010). Effect of sulphur and $\mathrm{GA}_{3}$ on growth and yield of onion. Progress.Agriculture, 21(1 \& 2): $57-63$.

Subhani, P. M., Ravishankar, C. and Narayan, N. (1990). Effect of graded level and time of application of $\mathrm{N}$ and $\mathrm{K}_{2} \mathrm{O}$ on flowering, fruiting and yield in irrigated chilli. Indian Cocoa, Arecanut and Spices, 14: 70-73.

Scott, T. (2007). What is the chemical process that causes my eyes to tear when I peel an onion? Ask the expert; Chemistry Scientific American. Retrieved on 8th April, 2007.

Tripathy, P; Sahoo,P; Priyadarshini, B. B; Das, A . S. K. and. Dash, D. K. (2013). Effect of Sources and Levels of Sulphur on Growth, Yield and Bulb Quality in onion (Allium cepa L.) International Journal of Bio-resource and Stress Management, 4(4): 641-644.

Vachhani, M. U. and Patel, Z. G. (1993). Effect of nitrogen, phosphorus and potash on bulb yield and quality of onion (Allium cepa). Indian Journal of Agronomy, 38: 333-334. 